\title{
PENGEMBANGAN MEDIA PEMBELAJARAN AUDIO VISUAL DENGAN ADOBE FLASH BERBASIS STANDAR PROSES KURIKULUM 2013 REVISI UNTUK SEKOLAH DASAR DI BALI
}

\author{
K.D.S. Udiyani ${ }^{1}$, D.M.S. Mardani ${ }^{2}$, I.W. Sadyana ${ }^{3}$ \\ ${ }^{123}$ Jurusan Bahasa Asing, Universitas Pendidikan Ganesha, Indonesia \\ e-mail : dwisavitri98@gmail.com,desak.mardani@undiksha.ac.id,
} wayan.sadyana@undiksha.ac.id

\begin{abstract}
Abstrak
Tujuan dari penelitian ini yaitu untuk membuat media pembelajaran audio visual dengan adobe flash berbasis kurikulum 2013 revisi untuk sekolah dasar di Bali. Jenis penelitian ini adalah penelitian pengembangan (research and development). Pengumpulan data dilakukan dengan menggunakan metode (1) wawancara dan (2) kuesioner berupa angket uji ahli (uji ahli isi, uji ahli media, dan uji coba produk) untuk membantu menghasilkan produk yang baik. Model pengembangan yang digunakan adalah model Four-D oleh Thiagarajan yang terdiri dari 4 tahapan yaitu (1) Define, (2) Design, (3) Develop, dan (4) Disseminate. Peneltian ini dilakukan hanya sampai pada tahap pengembangan (develop). Hasil penelitian menunjukkan bahwa (1) Media pembelajaran yang dikembangkan memuat pembelajaran HOTS. Media pembelajaran terdiri dari 10 bab. Media pembelajaran memuat latihan dan kalimat perintah. (2) Hasil angket uji ahli dan uji coba mendapat penilaian rata-rata 3 (setuju) dan 4 (sangat setuju). Dapat disimpulkan bahwa media pembelajaran audio visual berupa video animasi dengan adobe flash berbasis kurikulum 2013 revisi untuk sekolah dasar di Bali layak digunakan dalam proses pembelajaran..
\end{abstract}

Kata kunci: Media pembelajaran, audio visual, kurikulum 2013.

要旨

本研究の目的は、バリの小学校向けに改訂された2013年のカリキュラムに基づくアドビフラ ッシュを使用した視聴覚学習メディアを使うことである。本研究の種類は研究開発である。本研究の データは（1）面接と（2）実現可能性検討アンケート（専門家の検閲、専門家のデザイン検閲、実現 可能性検討）の形で行われ、優れた製品の生産に役に立った。学習メディアの作成に使用される開発 モデルは、（1）定義（2）設計（3）開発（4）普及の4つの部分からなるThiagarajanの 4Dモデルである。メディア開発は発展段階で実行されている、研究時間が限られている。結果、（1

）開発された学習メディアにはHOTSが含まれている。メディアには10の章が含まれている。学習メデ イアには、演習とコマンド文がある。（2）実現可能性検討と実現可能性検討の結果、3（適切）と4

(非常に適切）。2013年にバリの小学校向けに改訂されたカリキュラムに基づくアドビフラッシュを 備えた視聴覚学習メディアとアニメーションビデオは、学習プロセスでの使用に適していると結論付 けることができる。

キ一ワード : メディア開発、ビデオ、アドビフラッシュ、2013年カリキュラ

\section{Pendahuluan}

Menurut UU No. 20/2003 Kurikulum merupakan seperangkat rencana dan pengaturan mengenai tujuan, isi, dan bahan pelajaran serta cara yang digunakan sebagai pedoman penyelenggaraan kegiatan pembelajaran untuk mencapai tujuan pendidikan tertentu. Kurikulum di Indonesia beberapa kali mengalami perubahan. Kurikulum yang sekarang diberlakukan di Indonesia adalah kurikulum 2013 revisi. Poin penting dalam Kurikulum 2013 revisi yaitu meningkatkan hubungan atau keterkaitan antara kompetensi inti (KI) dan kompetensi dasar (KD). Kurikulum 2013 revisi menuntut pembelajaran yang sesuai dengan keterampilan abad 21.

Keterampilan abad 21 memadukan antara kecakapan pengetahuan, keterampilan, sikap, serta penguasaan terhadap Teknologi dan Informasi Komunikasi (TIK). Di dalam kurikulum 2013, keterampilan abad 21 tersebut termuat dalam PPK, Literasi, 4C, dan HOTS. Selain itu, 
prinsip pembelajaran kurikulum 2013 revisi salah satunya adalah guru bukanlah sebagai satu-satunya sumber belajar melainkan belajar berbasis aneka sumber seperti buku ajar maupun internet (Mardani,dkk.,2020). Oleh karena itu, penting adanya penggunaan media pembelajaran sebagai sarana untuk mendukung interaksi peserta didik dengan sumber belajarnya.

Berdasarkan hasil angket yang diberikan kepada 10 sekolah dasar di Bali yang sudah menerapkan pembelajaran bahasa Jepang, diperoleh data bahwa hanya 7 sekolah dasar yang menerapkan kurikulum 2013 revisi. Dari 11 responden 10 menyatakan perlu dibuatkan media pembelajaran berbasis kurikulum 2013 revisi dengan persentase 90,9\%. Sedangkan responden yang menyatakan memerlukan media pembelajaran bahasa Jepang sebanyak $45 \%$. Selain itu, berdasarkan hasil wawancara yang dilakukan kepada siswa di Sekolah Dasar yang bersamaan dengan penyebaran angket, diketahui bahwa dari 10 sekolah 43 siswa yang diwawancarai, terdapat 5 siswa yang menyatakan bahwa dalam proses pembelajaran hanya menggunakan media papan tulis.

Melalui hasil wawancara dan angket yang telah dilakukan, maka dibutuhkan media pembelajaran yang sesuai dengan perkembangan kognitif anak Sekolah Dasar dan tentunya sesuai dengan kurikulum 2013 revisi untuk sekolah dasar di Bali. Sehingga untuk mengatasi permasalahan tersebut yaitu dengan menggunakan media pembelajaran bahasa Jepang audio visual berbasis adobe flash.

Berdasarkan hasil wawancara dan angket analisis kebutuhan yang sudah disebarkan, dinyatakan bahwa Sekolah Dasar di Bali yang memerlukan media pembelajaran yang sesuai dengan kurikulum 2013 revisi adalah sebanyak 90,9\%. Dan juga media pembelajaran yang sesuai dengan perkembangan kognitif anak sekolah dasar. Sehingga dengan masih adanya permasalahan tersebut, maka dilakukan penelitian pengembangan media pembelajaran bahasa Jepang audio visual berbasis adobe flash dengan standar proses kurikulum 2013 revisi untuk sekolah dasar di Bali.

Penelitian sejenis dilakukan oleh Keniten (2017) yang meneliti tentang pengembangan media pembelajaran bahasa Jepang berbasis adobe flash. Pengembangan media ini dilakukan di SMK Negeri 4 Negara. Pengembangan media ini bertujuan untuk memudahkan siswa dalam mengingat kosakata bahasa Jepang diajarkan. Penelitian yang dilakukan oleh Keniten (2017) dikatakan bahwa media pembelajaran kosakata bahasa Jepang berbasis adobe flash sudah sesuai dengan silabus dan layak digunakan dalam pembelajaran, dapat meningkatkan minat siswa dalam belajar dan siswa lebih aktif mengikuti pembelajaran sehingga mampu mempermudah sistwa dalam mengingat kosakata bahasa Jepang.

Disebutkan pula media pembelajaran berbasis adobe flash sangat efektif digunakan untuk membantu meningkatkan motivasi siswa dan mempermudah proses pembelajaran, maka peneliti tertarik untuk mengembangkan media pembelajaran bahasa Jepang audio visual berbasis adobe flash yang sesuai dengan standar proses kurikulum 2013 revisi untuk sekolah dasar di Bali. Berdasarkan latar belakang tersebut, maka dapat dirumuskan masalah dalam penelitian ini yaitu "Bagaimanakah Pengembangan Media Pembelajaran Bahasa Jepang Audio Visual Berbasis Adobe Flash dengan Standar Proses Kurikulum 2013 Revisi untuk Sekolah Dasar di Bali?"

Tujuan dari penelitian ini diharapkan untuk mengembangkan media pembelajaran berbasis kurikulum 2013 revisi yang digunakan sebagai penunjang proses pembelajaran bahasa Jepang untuk SD di Bali.

\section{Metode}

\section{Model Penelitian Pengembangan}

Dalam penelitian ini, model pengembangan yang digunakan dalam pembuatan media pembelajaran adalah 4-D yang dikembangkan oleh S. Thiagarajan, Dorothy S. Semmel, dan Melvyn L Semmel (1974: 5) (dalam Mulyatiningsih, 2016) yang terdiri atas empat tahap utama diantaranya yaitu Define (Pendefinisian), Design (Perancangan), Develop (Pengembangan) dan Disseminate (Penyebaran). Namun, pada pengembangan media pembelajaran audio visual berbasis adobe flash ini tidak dilakukan sampai tahap keempat, 
namun dibatasi hanya sampai tahap ketiga yaitu Develop (Pengembangan) karena terbatasnya waktu penelitian.

\section{Prosedur Penelitian Pengembangan}

Dalam penelitian ini, model pengembangan media pembelajaran yang digunakan adalah model pengembangan 4-D. Menurut S. Thiagarajan, Dorothy S. Semmel, dan Melvyn L Semmel (dalam Mulyatiningsih, 2016) model pengembangan 4-D ini memiliki empat tahap utama diantaranya yaitu.

1. Tahap 1 : Define

Tahap ini disebut dengan tahap analisis kebutuhan. Pada tahap ini dilakukan dengan memberikan angket dan melakukan wawancara, angket diberikan kepada guru pengajar bahasa Jepang sedangkan wawancara dilakukan dengan siswa sekolah dasar di Bali yang menerapkan pembelajaran bahasa Jepang. Berdasarkan hasil wawancara dan angket yang telah disebarkan, diketahui bahwa dalam proses pembelajaran bahasa Jepang sekolah dasar di Bali mengalami masalah, yaitu belum tersedianya media pembelajaran yang sesuai dengan perkembangan kognitif anak sekolah dasar dan yang sesuai dengan kurikulum 2013 revisi.

2. Tahap 2 : Design

Kegiatan pada tahap ini,yaitu membuat rancangan awal produk media pembelajaran. Pada tahap ini dilakukan dengan membuat rancangan produk, seperti melakukan pemilihan terhadap aplikasi yang digunakan dalam pembuatan media pembelajaran, membuat konsep media seperti apa yang akan dibuat, dan melakukan pemilihan gambar yang sesuai dengan kosakata yang akan ditampilkan dalam media pembelajaran. Media pembelajaran yang dibuat merupakan media pembelajaran audio visual dengan adobe flash berbasis standar proses kurikulum 2013 revisi untuk sekolah dasar di Bali.

3. Tahap 3 : Develop

Tahap ini merupakan tahap uji ahli produk yang telah dibuat. Kemudian, setelah melakukan uji ahli, dilakukan revisi akhir yang sesuai dengan komentar, masukan dan saran dari penguji ahli. Setelah revisi akhir selesai, selanjutnya dilakukan uji coba secara terbatas terhadap guru dan siswa sekolah dasar untuk mengetahui kelayakan media pembelajaran yang telah dibuat.

4. Tahap 4 : Disseminate

Kegiatan pada tahap ini yaitu penyebarluasan produk. Namun, dalam penelitian ini tahap keempat ini tidak dilakukan karena keterbatasan waktu penelitian.

A. Uji Coba Produk

1. Desain Uji Coba

Uji coba yang akan dilakukan dalam penelitian ini adalah uji coba terbatas. Uji coba terbatas dilakukan untuk melihat respon siswa dan guru ketika diperlihatkan produk media pembelajaran audio visual berbasis adobe flash.

2. Subjek Uji Coba

Pada penelitian pengembangan ini yang menjadi subjek uji coba adalah guru pengajar bahasa Jepang dan siswa sekolah dasar di Bali yang mempelajari bahasa Jepang. Namun, uji coba ini dilakukan secara terbatas di SD Mutiara Singaraja. Uji coba dilakukan kepada guru pengajar dan 43 siswa peserta ekstrakurikuler bahasa Jepang yang terdiri atas kelas 4,5 , dan 6 .

3. Jenis Data

Jenis data yang digunakan dalam penelitian ini adalah angket dan wawancara, data yang didapatkan bertujuan untuk mengetahui kebutuhan dan masalah yang ada didalam pembelajaran bahasa Jepang yang sesuai dengan kurikulum 2013 revisi pada sekolah dasar di Bali.

\section{Metode dan Instrumen Pengumpulan Data}

Pada penelitian ini, untuk mengumpulkan dan menganalisis data menggunakan dua instrumen pengumpulan data, yaitu wawancara dan angket. Wawancara ini dilakukan dengan siswa sekolah dasar untuk mengetahui media pembelajaran apa saja yang telah 
digunakan dalam proses pembelajaran. Pada penelitian ini, angket digunakan untuk mengetahui analisis kebutuhan dengan memberikan angket kepada guru bahasa Jepang sekolah dasar di Bali. Kemudian, angket juga digunakan untuk melakukan uji ahli isi, uji ahli media serta uji coba produk.

Metode dan Teknik Analisis Data

Hasil angket uji ahli dan uji coba terbatas terhadap guru dihitung dengan menggunakan rumus sebagai berikut.

Tabel 1. Kriteria Tingkat Validitas Perangkat Pembelajaran

\begin{tabular}{|c|c|}
\hline Skor & Kriteria \\
\hline $76<\mathrm{SR} \leq 100$ & Sangat Sesuai (SS) \\
\hline $51<\mathrm{SR} \leq 75$ & Sesuai (S) \\
\hline $26<\mathrm{SR} \leq 50$ & Kurang Sesuai (KS) \\
\hline $0<\mathrm{SR} \leq 25$ & Tidak Sesuai (TS) \\
\hline
\end{tabular}

Rumus :

$$
\text { Kirna (dalam Triantari, 2018) }
$$

$$
S R=\frac{\text { Jumlah skor dalam semua item }}{\text { Jumlah skor maksimal }} \times 100
$$

Keterangan :

$\mathrm{SR}=$ Skor rata-rata berdasarkan hasil validasi

Dalam penelitian ini, skor rata-rata maksimal yang harus dicapai yaitu interval $51<\mathrm{SR} \leq 75$. Dengan demikian perangkat pembelajaran yang dikembangkan dapat dinyatakan layak digunakan.

Adapun hasil angket uji coba yang telah diberikan kepada peserta didik dihitung dengan rumus sebagai berikut.

$$
x=\sum x-n
$$

Keterangan :

$\mathrm{X}=$ Jumlah responden yang menyatakan setuju

$\mathrm{n}=$ Jumlah responden yang menyatakan tidak setuju

$\sum \mathrm{x}=$ Total seluruh jumlah responden

Kemudian jumlah responden yang menyatakan setuju sudah diperoleh, maka kembali dihitung untuk mmendapatkan hasil presentase kelayakan media. Dengan rumus sebagai berikut.

$$
\text { Hasil }=\frac{\text { Jumlah total responden setuju }}{\text { Jumlah indikator }} \times 100
$$

Tabel 2. Kriteria Kelayakan Media

\begin{tabular}{|c|c|}
\hline Skor dalam persen & Kategori kelayakan \\
\hline$<21 \%$ & Sangat Tidak Layak \\
\hline $21-40 \%$ & Tidak Layak \\
\hline $41-60 \%$ & Cukup Layak \\
\hline
\end{tabular}




\begin{tabular}{|c|c|}
\hline $61-80 \%$ & Layak \\
\hline $81-100 \%$ & Sangat Layak \\
\hline \multicolumn{2}{|c|}{ Arikunto (dalam lis dan Totok, 2017:207) }
\end{tabular}

Dalam penelitian ini, skor rata-rata maksimal yang harus dicapai yaitu interval $81-100 \%$. Dengan demikian perangkat pembelajaran yang dikembangkan dapat dinyatakan layak digunakan.

\section{Hasil dan Pembahasan}

\section{Penyajian Data Uji Coba}

Media Pembelajaran yang dikembangkan dalam penelitian ini adalah media pembelajaran audio visual berbasis adobe flash yang dapat digunakan sebagai alat bantu dalam proses pembelajaran bahasa Jepang untuk sekolah dasar. Media pembelajaran audio visual berbasis adobe flash ini didalamnya memuat berbagai kosakata dasar bahasa Jepang untuk siswa sekolah dasar. Media pembelajaran ini terdiri atas 10 bab dan menyajikan materi yang meliputi: (1) pekerjaan keluarga (kazoku no shigoto); (2) Nama-nama negara (kokumei); (3) Letak suatu benda; (4) Hobi (shumi); (5) Kepemilikan benda; (6) Kondisi benda; (7) Kegiatan Sehari-hari (mai nichi); (8) Jadwal kegiatan di rumah; (9) Kegiatan berurutan; (10) Berwisata dalam bahasa Jepang. Dalam media pembelajaran ini, di setiap bab terdapat gambar dan suara yang dapat membantu siswa memahami materi dan membuat siswa tertarik untuk mempelajari bahasa Jepang.

Adapun penjabaran dari media pembelajaran yang telah dibuat, yaitu

1. Bab 21 - Pekerjaan Anggota Keluarga (kazoku no shigoto)

Pada bab ini, menjelaskan tentang beberapa jenis pekerjaan anggota keluarga dalam bahasa Jepang.

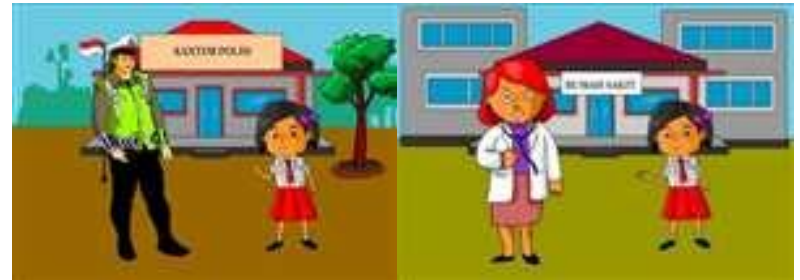

Gambar 1. Gambar media materi bab kazoku no shigoto

2. Bab 22 - Nama - Nama Negara (kokumei)

Pada bab ini, menjelaskan tentang beberapa macam nama Negara yang ada di dunia dalam bahasa Jepang.

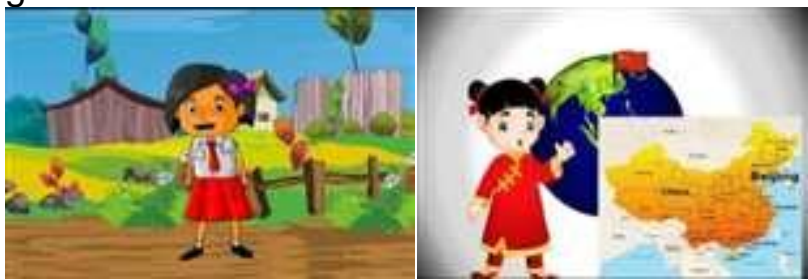

Gambar 2. Gambar media materi bab kokumei

3. Bab 23 - Letak Benda

Pada bab ini, menjelaskan tentang letak benda yang ada di dalam rumah dalam bahasa Jepang.

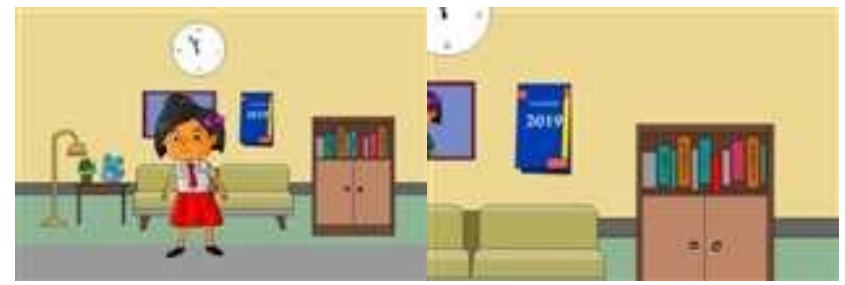

Gambar 3. Gambar media materi bab letak benda

4. Bab $24-$ Hobi (Shumi)

Pada bab ini, menjelaskan tentang beberapa macam hobi dalam bahasa Jepang. 


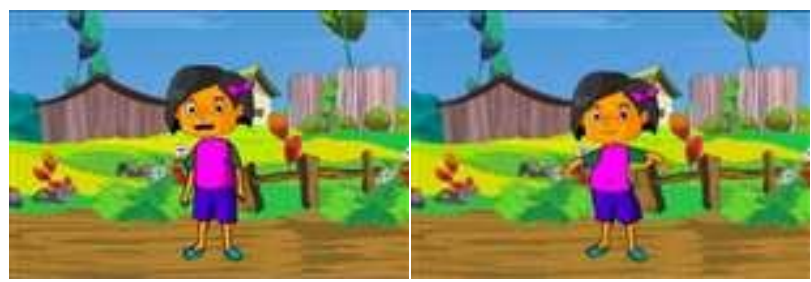

Gambar 4. Gambar media materi bab shumi

5. Bab 25 - Kepemilikan Benda

Pada bab ini, menjelaskan tentang benda yang dimiliki dalam satu keluarga yang ada di dalam rumah dalam bahasa Jepang.

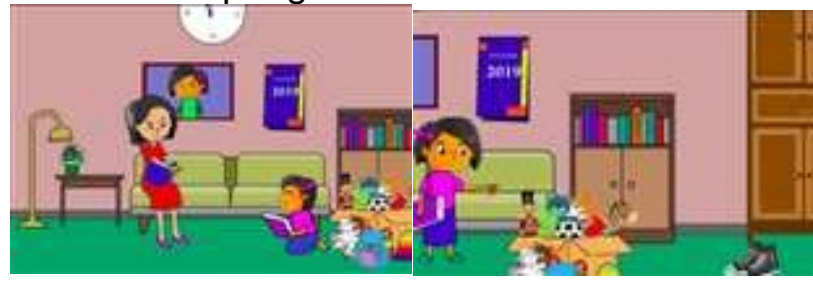

6. Bab 26 - Kondisi Benda

Gambar 5. Gambar media materi bab kepemilikan benda

Pada bab ini, menjelaskan tentang kondisi suaru ruangan yang ada di rumah dalam bahasa Jepang.

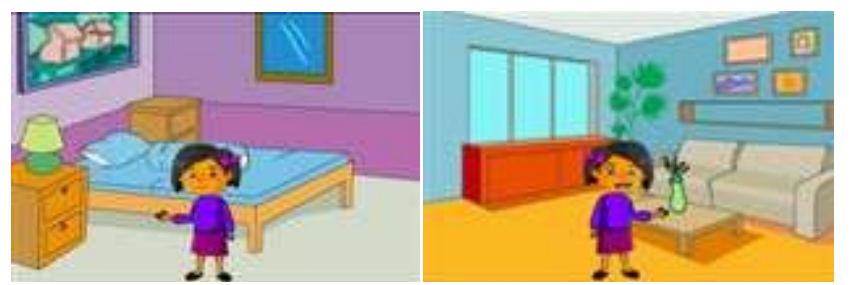

Gambar 6. Gambar media materi bab kondisi benda

7. Bab 27 - Kegiatan Sehari-hari (Mai nichi)

Pada bab ini, menjelaskan tentang siswa yang menceritakan kegiatan sehari-harinya di depan kelas dalam bahasa Jepang.

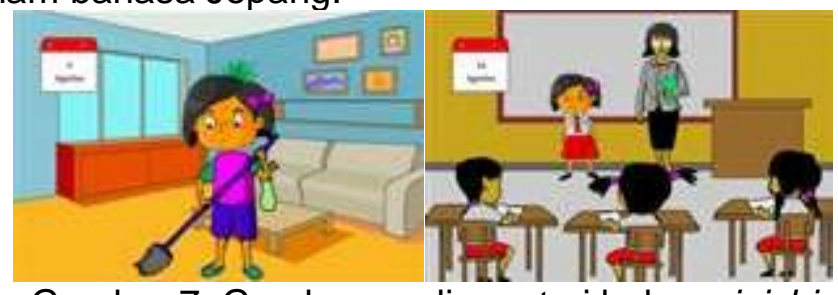

Gambar 7. Gambar media materi bab mainichi

8. Bab 28 - Jadwal Kegiatan di Rumah

Pada bab ini, menjelaskan tentang jadwal kegiatan sehari-hari dalam bahasa Jepang.

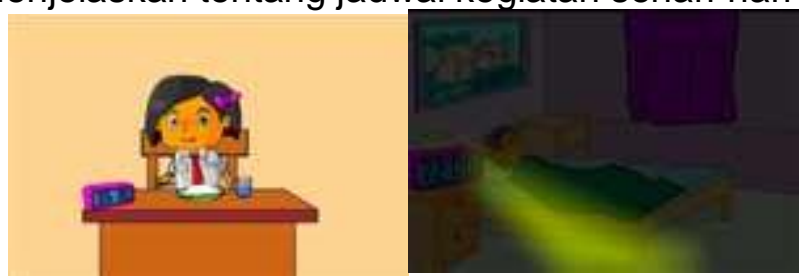

Gambar 8. Gambar media materi bab jadwal kegiatan di rumah

9. Bab - 29 Kegiatan Berurutan

Pada bab ini, menjelaskan tentang siswa yang menceritakan kegiatan sehari-harinya di depan kelas secara berurutan dalam bahasa Jepang. 


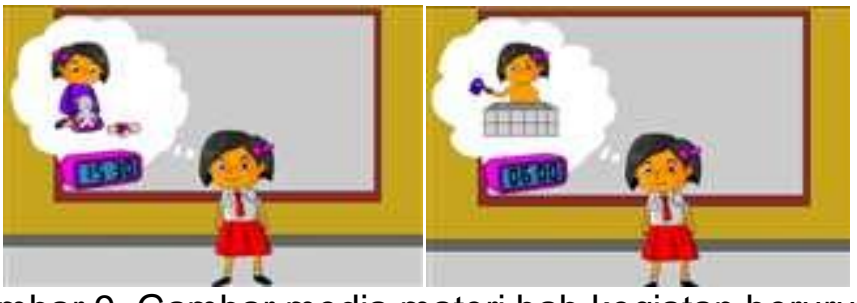

10. Bab - 30 Berwisata

Gambar 9. Gambar media materi bab kegiatan berurutan

Pada bab ini, menjelaskan tentang mengajak teman beraktivitas dalam bahasa Jepang.

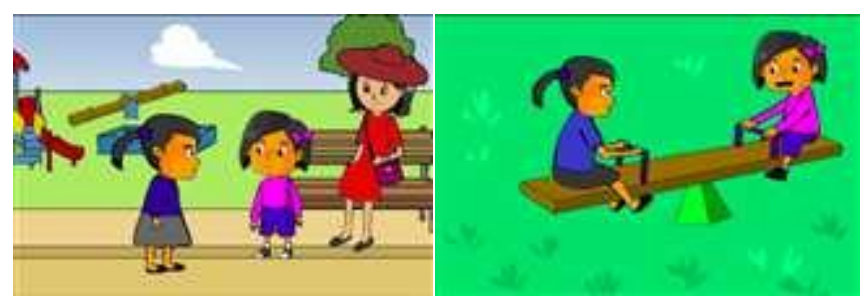

Gambar 10. Gambar media materi bab berwisata

Hasil Analisis Angket Uji Ahli

Sebelum menghasilkan media pembelajaran yang layak untuk digunakan, telah dilakukan tahap uji ahli agar menghasilkan produk yang berkualitas dan sesuai dengan kebutuhan. Tahap uji ahli dilakukan dengan memberikan angket yang berisi sejumlah pernyataan mengenai isi materi dan media pembelajaran kepada para ahli untuk melakukan penilaian terhadap produk media pembelajaran yang telah dikembangkan. Selain itu, angket diberikan kepada guru dan peserta didik untuk mengetahui kelayakan, serta respon terhadap media yang dikembangkan. Penilaian angket menggunakan penilaian skala 4 yakni $1=$ Sangat Tidak Setuju (STS), 2 = Tidak Setuju (TS), 3 = Setuju (S), 4 = Sangat Setuju (SS).

Angket uji ahli isi diberikan kepada Dosen Program Studi Pendidikan Bahasa Jepang, Universitas Pendidikan Ganesha. Angket ini diberikan kepada dosen pada 22 Januari 2020. Untuk uji ahli isi mendapat skor 87,5 yang masuk ke dalam interval $76<$ SR $\leq 100$ yaitu sangat sesuai.

Angket uji ahli media diberikan kepada Dosen Program Studi Desain Komunikasi Visual Universitas Pendidikan Ganesha. Angket ini diberikan kepada dosen pada 21 Januari 2020. Untuk uji ahli media mendapat skor 91,6 yang masuk ke dalam interval $76<$ SR $\leq 100$ yaitu sangat sesuai.

Angket uji coba produk diberikan kepada guru pengajar SD Mutiara Singaraja. Angket ini diberikan pada tanggal 7 Februari 2020. Untuk uji coba dengan guru mendapat skor 82,7 yang masuk ke dalam interval $76<\mathrm{SR} \leq 100$ yaitu sangat sesuai. Selain itu, angket uji coba juga diberikan kepada kepada 36 siswa SD Mutiara Singaraja. Angket ini diberikan pada tanggal 14 Februari 2020. Untuk uji coba dengan siswa mendapat skor 85, 48 yang masuk ke dalam interval $76<\mathrm{SR} \leq 100$ yaitu sangat sesuai.

A. Hasil Analisis Data

Sebelum menghasilkan media pembelajaran yang layak untuk digunakan, telah dilakukan tahap uji ahli agar menghasilkan produk yang berkualitas dan sesuai dengan kebutuhan. Media pembelajaran yang dikembangkan sudah melakukan beberapa tahap perbaikan dengan memperbaiki desain background dan gambar agar lebih sesuai dengan materi dan lebih menarik untuk dipertontonkan. Tahap uji ahli dilakukan oleh dua orang penguji ahli yang diantaranya, Uji ahli isi yang dilakukan oleh dosen Program Studi Pendidikan Bahasa Jepang Universitas Pendidikan Ganesha, uji ahli media yang dilakukan oleh dosen Program Studi Desain Komunikasi Visual Universitas Pendidikan Ganesha.

Berdasarkan penilaian uji ahli isi terhadap media yang dikembangkan yaitu pada aspek cakupan materi dikatakan sudah sesuai karena materi dan kosakata yang digunakan sudah sesuai dengan materi untuk tingkat anak sekolah dasar. Pada aspek akurasi materi (kesesuaian dan ketepatan dikatakan sudah sesuai karena materi yang digunakan sudah 
akurat, gambar yang digunakan dalam media sudah sesuai dengan kosakata. Pada aspek komponen penyajian, dianggap sudah sesuai, hanya perlu ditambahkan penutup pada setiap bab. Secara keseluruhan penguji ahli isi memberikan masukan untuk menambahkan penutup disetiap video dan pertimbangkan untuk menambah latihan kosakata singkat di akhir video.

Berdasarkan penilaian uji ahli media terhadap media yang dikembangkan yaitu pada aspek tampilan media mendapat masukan yaitu ada beberapa background yang perlu untuk digambar ulang agar lebih bagus karena pixel yang pecah, jadi gambar terlihat kurang jelas. Pada aspek isi dalam media, mendapat masukan yaitu karakter tokoh pada video bab 22 perlu diperbaiki agar mewakili Negara tersebut, misalnya, warna rambut animasi gambar orang Cina. Pada aspek efisien media tidak mendapat masukan dari penguji. Pada aspek kualitas media, mendapat masukan yaitu dubbing pada beberapa dialog perlu direvisi agar stabil dalam volume suara karakter, karena ada beberapa volume suara yang terlalu keras sehingga tidak sama dengan volume suara pada bab lainnya.

Penilaian uji coba terbatas dilakukan oleh guru pengajar bahasa Jepang dan 36 siswa di SD Mutiara Singaraja. Berdasarkan penilaian uji coba terbatas terhadap media yang dikembangkan yaitu kosakata yang digunakan dalam video sudah sesuai dengan materi tingkat sekolah dasar. Penyajian video juga sudah menarik sehingga memudahkan pemahaman siswa dalam belajar khususnya bahasa Jepang. Selain itu, berdasarkan penilaian dari siswa yaitu siswa suka dan lebih mudah memahami materi pembelajaran ketika belajar bahasa Jepang menggunakan media pembelajaran. Media pembelajaran juga dikatakan menarik sehingga siswa memiliki minat yang lebih dalam belajar.

\section{Revisi Produk}

Setelah melakukan uji ahli isi dan ahli media, dilakukan revisi untuk menghasilkan produk yang lebih baik dan layak untuk digunakan. Berikut dipaparkan beberapa hal yang perlu dilakukan perbaikan, yaitu sebagai berikut.

1. Judul bab

Berdasarkan penilaian dari penguji ahli isi, perlu ditambahkan judul pada setiap media pembelajaran. Judul bab tersebut dapat diletakkan di bagian awal media pembelajaran ataupun di bagian penamaan pada folder. Ditambahkan judul bab dirasa penting untuk memudahkan pengguna ketika mencari materi yang diperlukan.

2. Penambahan suara pengucapan bahasa Jepang

Berdasarkan penilaian dari penguji ahli isi, pada setiap bab media pembelajaran perlu ditambahkan pertanyaan dan penutup. Pertanyaan diisi untuk dijadikan sebagai latihan kepada siswa untuk mengetahui pemahaman siswa terkait materi yang telah disampaikan. Sedangkan, penutup penting untuk diisi sebagai penanda bahwa media pembelajaran tersebut telah berakhir.

3. Perubahan warna gambar masakan

Berdasarkan penilaian dari uji ahli media, warna makanan dalam media pembelajaran pada bab Pekerjaan dirasa tidak sesuai. Di dalam kehidupan nyata jarang ditemukan makanan yang berwarna biru sehingga perlu dilakukan perbaikan terhadap warna makanan tersebut.

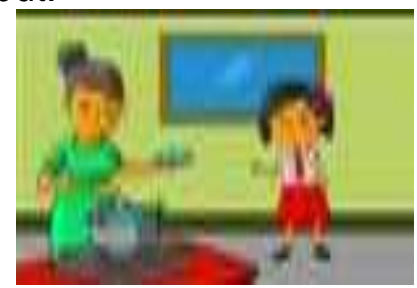

Sebelum Revisi

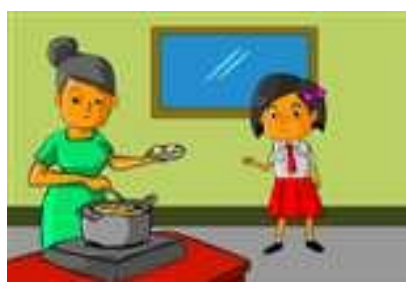

Setelah revisi

Gambar 11. Revisi gambar warna masakan

\section{Perubahan background}

Berdasarkan penilaian dari uji ahli media, terdapat background yang kurang jelas di beberapa bab media pembelajaran. Background dirasa kurang jelas dan pixel pecah 
sehingga terlihat berbeda dengan background lainnya yang terlihat jelas. Maka dari itu, perlu dilakukan pengulangan pembuatan beberapa background agar terlihat lebih jelas dan tidak buram sehingga selaras dengan background yang lainnya dalam media.

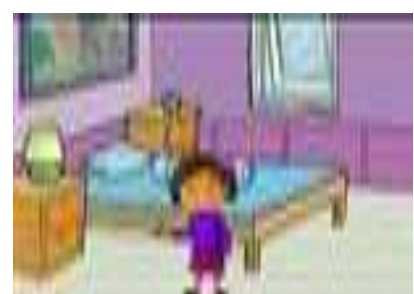

Sebelum Revisi

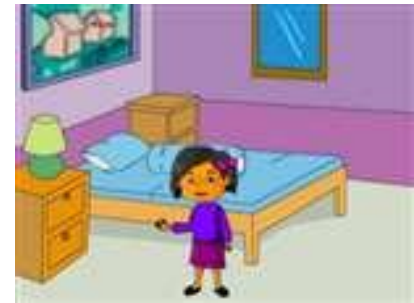

Sesudah Revisi

Gambar 12. Revisi gambar background Kamar Tidur

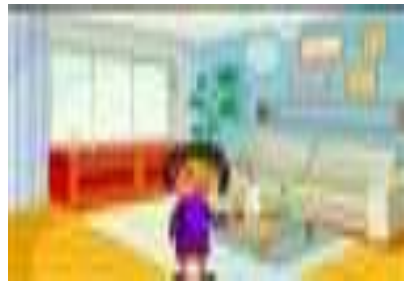

Sebelum revisi

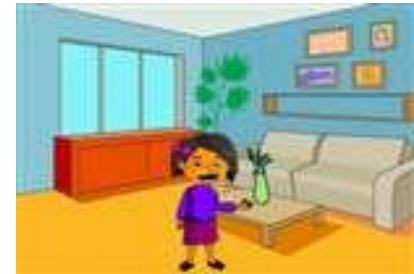

Sesudah Revisi Gambar 13. Revisi gambar background Ruang Tamu

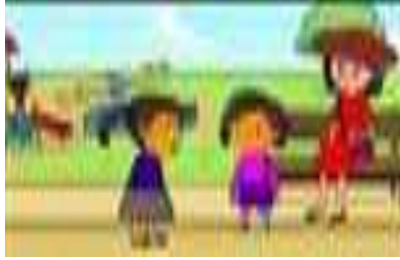

Sebelum Revisi

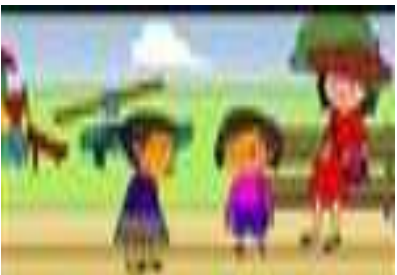

Sesudah Revisi

Gambar 14. Revisi gambar background Taman Bermain

5. Perubahan gambar rambut pada animasi orang Cina

Berdasarkan penilaian dari uji ahli media, animasi orang Cina pada bab nama-nama Negara dirasa kurang sesuai dengan ciri khas orang Cina pada umumnya. Ciri khas orang Cina yang memiliki rambut panjang dengan poni depan yang lurus berwarna hitam.

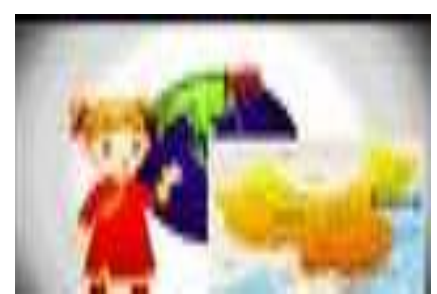

Sebelum revisi

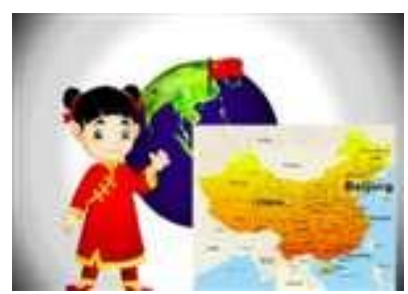

Setelah revisi

Gambar 15. Revisi gambar warna rambut

Pembahasan Hasil Penelitian

Hasil yang didapatkan dari penelitian ini, berdasarkan hasil angket yang diberikan kepada guru pengajar sekolah dasar di Bali ditemukan masalah, yaitu belum tersedianya media pembelajaran yang sesuai dengan kurikulum yang sekarang diberlakukan, yaitu kurikulum 2013 revisi. Juga terdapat sekolah yang tidak menggunakan media pembelajaran dalam proses pembelajaran di kelas. Berdasarkan hasil angket tersebut dinyatakan bahwa perlu dibuatkan media pembelajaran berbasis kurikulum 2013 revisi dengan persentase 90,9 $\%$. Sehingga dengan adanya permasalahan tersebut, maka dilakukan pengembangan media 
pembelajaran bahasa Jepang audio visual berbasis adobe flash dengan standar proses kurikulum 2013 revisi untuk sekolah dasar di Bali.

Media pembelajaran audio visual berbasis adobe flash dikembangkan karena efektif dan efisien digunakan dalam proses pembelajaran. Juga dapat menarik perhatian dan minat siswa dalam belajar. Oleh karena itu, kehadiran media pembelajaran sangat diperlukan sebagai sarana pendukung dalam proses pembelajaran. Selain itu, berdasarkan wawancara yang telah dilakukan kepada siswa, dinyatakan bahwa dalam proses pembelajaran di kelas, guru dalam menyampaikan materi pembelajaran menggunakan beberapa alat bantu diantaranya yaitu kartu gambar, papan tulis, buku, benda asli dan gambar yang ditampilkan pada $I c d$. Jadi, dapat disimpulkan bahwa sangat diperlukan adanya media pembelajaran audio visual untuk meningkatkan kemampuan siswa dalam melihat, mendengar maupun berbicara yang sesuai dengan arahan dari media pembelajaran, sehingga dengan melatih kemampuan tersebut, siswa akan lebih mudah memahami pembelajaran yang telah disampaikan.

Pengembangan media pembelajaran audio visual dengan adobe flash dilakukan dengan menggunakan model penelitian pengembangan 4-D yang memiliki empat tahap. Dimulai dari tahap Define (Pendefinisian) yang disebut dengan tahap analisis kebutuhan. Pada tahap ini dilakukan dengan memberikan angket dan melakukan wawancara, angket diberikan kepada guru pengajar bahasa Jepang sedangkan wawancara dilakukan dengan siswa sekolah dasar di Bali yang menerapkan pembelajaran bahasa Jepang. Selanjutnya tahap Design (Perancangan) disebut tahap membuat rancangan awal produk media pembelajaran. Pada tahap ini dilakukan dengan membuat rancangan produk, seperti melakukan pemilihan terhadap aplikasi yang digunakan dalam pembuatan media pembelajaran, membuat konsep media seperti apa yang akan dibuat, dan melakukan pemilihan gambar yang sesuai dengan kosakata yang akan ditampilkan dalam media pembelajaran.

Kemudian dilanjutkan dengan tahap Develop (Pengembangan) disebut sebagai tahap untuk melakukan uji ahli produk yang telah dibuat. Kemudian, setelah melakukan uji ahli, dilakukan revisi akhir yang sesuai dengan komentar, masukan dan saran dari penguji ahli. Setelah revisi akhir selesai, selanjutnya dilakukan uji coba secara terbatas terhadap guru dan siswa sekolah dasar untuk mengetahui kelayakan media pembelajaran yang telah dibuat. Selanjutnya terakhir tahap Disseminate (Penyebaran) disebut sebagai tahap penyebarluasan produk. Namun, dalam penelitian ini tahap keempat ini tidak dilakukan karena keterbatasan waktu penelitian.

Pengembangan media pembelajaran ini dibuat menggunakan aplikasi adobe flash. Gambar yang dibuat pada aplikasi adobe flash merupakan gambar buatan sendiri dan gambar yang telah ada di internet yang kemudian di gambar ulang. Dalam media pembelajaran ini dibuat gambar tokoh animasi yang lucu, juga gambar-gambar yang ada dalam media disesuaikan dengan benda yang ada disekitar lingkungan siswa. Selain gambar, media ini memuat suara. Selain itu, dalam media pembelajaran juga memuat kalimat perintah dan soal latihan yang membantu siswa lebih aktif dalam proses pembelajaran. Juga dapat membantu siswa memahami materi pembelajaran yang telah dipelajarinya.

Media pembelajaran ini dikembangkan sesuai dengan kurikulum 2013 revisi yang didalamnya memuat pembelajaran berbasis HOTS (Higher Order of Thinking Skill). Dalam media ini, pembelajaran berbasis HOTS sudah meliputi tahap mengetahui, memahami, mengaplikasi, dan menganalisis. Materi yang terdapat pada media pembelajaran audio visual dengan adobe flash ini mengenalkan kosakata dan pola kalimat melalui pengucapan dalam bahasa Jepang yang dibantu dengan gambar untuk meningkatkan kemampuan siswa dalam mengingat kosakata serta memahami maksud dari materi yang telah disampaikan pada media pembelajaran tersebut.

Tahap pertama yaitu mengetahui, dalam media pembelajaran ini disampaikan kosakata bahasa Jepang dan siswa diajak untuk mengulang kembali pengucapan kosakata bahasa Jepang tersebut agar meningkatkan kemampuan siswa untuk mengingat. Contohnya pada materi bab nama-nama Negara terdapat kosakata nama-nama Negara serta pengucapan pola kalimat yang digunakan. Pada materi itu juga terdapat kalimat perintah yang mengajak 
siswa bersama-sama untuk mengucapkan kosakata dan pola kalimat tersebut. Selain materi bab nama-nama Negara, pada materi bab kegiatan yang berurutan, konsep yang ada pada materi ini terdapat animasi seorang siswa yang menyampaikan aktivitasnya sehari-hari di depan kelas dengan pengucapan bahasa Jepang. Pada materi bab tersebut juga terdapat pertanyaan yang menuntut siswa mengucapkan kembali kegiatan apa saja yang dilakukan animasi seorang siswa tersebut. Sehingga dengan melakukan pengulangan mengucapkan pola kalimat bahasa Jepang tersebut, diharapkan siswa lebih mudah mengingat materi pembelajaran yang telah didapat.

Selanjutnya pada tahap memahami, dalam media ini siswa diharapkan mampu memahami keterkaitan antara gambar dengan pengucapan bahasa Jepang yang terdapat pada setiap media. Dalam media pembelajaran, setiap materi bab memiliki konsep yang berbeda-beda untuk menyampaikan maksud materi pembelajaran. Sehingga siswa diharapkan mampu memahami keterkaitan antara pengucapan bahasa Jepang dengan gambar yang ditampilkan melalui konsep yang digunakan pada setiap media pembelajaran.

Kemudian pada tahap mengaplikasikan, siswa dituntut mampu mengaplikasikan dan menerapkan pembelajaran yang telah didapatkan sebelumnya. Contohnya pada materi bab pekerjaan keluarga, dalam media tersebut terdapat pertanyaan yang menuntut siswa untuk mengungkapkan pekerjaan dalam keluarganya. Selain pada bab pekerjaan keluarga, pada materi bab kondisi benda juga terdapat pertanyaan yang menuntut siswa untuk menyampaikan kondisi rumahnya. Selain itu, dalam setiap media pembelajaran terdapat kalimat perintah dan pertanyaan yang menuntut siswa untuk berbicara bahasa Jepang. Hal tersebut sudah masuk kedalam tahap mengaplikasikan, karena melatih kemampuan siswa dalam berbicara bahasa Jepang.

Kemudian pada tahap selanjutnya yaitu menganalisis. Pada tahap ini siswa dituntut mampu untuk melakukan analisis. Contohnya, pada materi bab kepemilikan benda terdapat konsep kore, sore, are yang menuntut siswa dapat membandingkan penggunaan konsep tersebut. Kemampuan siswa untuk membandingkan konsep tersebut merupakan penerapan dari tahap menganalisis. Juga pada beberapa materi bab yang ada dalam media pembelajaran menggunakan konsep percakapan untuk menyampaikan materi pembelajaran. Dengan menggunakan konsep tersebut, siswa dituntut mampu memahami keterkaitan antara konsep pola kalimat bahasa Jepang yang diaplikasikan melalui percakapan dengan gambar yang ditampilkan pada media tersebut. Jadi dapat disimpulkan bahwa media pembelajaran audio visual dengan adobe flash yang telah dikembangkan ini sudah sesuai dengan kurikulum 2013 revisi yang di dalamnya telah memuat pembelajaran berbasis HOTS.

Setelah media pembelajaran dikembangkan, dilakukan uji ahli dan uji coba terbatas. Uji ahli dilakukan dengan dua orang penguji. Uji ahli isi mendapat skor 87,5 dan uji ahli media mendapat skor 91,6. Kemudian, uji coba dilakukan dengan guru pengajar dan siswa di SD Mutiara Singaraja. Uji coba dari guru mendapat skor 82,7 dan dari siswa mendapat skor 85,48 . Karena keterbatasan waktu, uji coba dilakukan secara terbatas untuk melihat respon siswa dan guru ketika diperlihatkan media pembelajaran yang telah dibuat. Berdasarkan hasil uji ahli yang telah dilakukan oleh penguji dan hasil uji coba dari guru dan siswa, maka media pembelajaran ini layak untuk digunakan oleh sekolah dasar dalam proses pembelajaran.

Dengan demikianlah media pembelajaran audio visual berbasis adobe flash ini penting dikembangkan, sehingga dapat dipergunakan oleh guru dan siswa sebagai alat bantu dalam proses pembelajaran bahasa Jepang sekolah dasar.

\section{Simpulan dan Saran}

Simpulan dari penelitian ini adalah media pembelajaran audio visual dengan adobe flash ini telah layak digunakan dalam kegiatan pembelajaran di kelas. Media ini juga sudah sesuai dengan standar proses kurikulum 2013 revisi dan karakteristik anak sekolah dasar. Media pembelajaran ini dibuat sesuai dengan hasil angket yang telah disebarkan dan silabus yang sesuai dengan kurikulum 2013 revisi. Media pembelajaran ini terdiri atas 10 bab yang memuat materi sebagai berikut, kazoku no shigoto, kokumei, letak benda, shumi, kepemilikan benda, kondisi benda, mainichi, jadwal kegiatan di rumah, kegiatan berurutan, 
dan berwisata. Selain itu, didalam media ini memuat kalimat perintah dan pertanyaan yang dapat dijadikan sebagai latihan untuk mengukur pemahaman siswa akan materi yang telah disampaikan

Berdasarkan penilaian uji ahli isi dan uji coba, media pembelajaran audio visual dengan adobe flash ini dinilai sudah sangat sesuai. Skor rata-rata dari hasil angket uji ahli isi mendapat skor 87.5 dan uji ahli media mendapat skor 91.6. Kemudian hasil angket uji coba terbatas dengan guru mendapat skor 82.7 dan dengan siswa mendapat skor 85.48. Dengan demikian media pembelajaran audio visual dengan adobe flash yang telah dibuat ini layak untuk digunakan dalam proses pembelajaran bahasa Jepang sekolah dasar di Bali.

Saran yang dapat disampaikan kepada peneliti lainnya yaitu diharapkan dapat mengembangkan media pembelajaran bahasa Jepang untuk sekolah dasar yang disesuaikan dengan kurikulum yang berlaku. Selanjutnya, dapat mengembangkan media pembelajaran yang didalamnya memuat cakupan materi yang lebih luas. Kemudian di dalam media pembelajaran diharapkan memuat pertanyaan-pertanyaan yang lebih banyak dan bervariatif sehingga dapat membantu proses pembelajaran, serta dapat mengembangkan media pembelajaran yang lebih baik dan lebih menarik.

\section{Daftar Pustaka}

lis \& Totok. 2017. "Uji Kelayakan Media Pembelajaran Interaktif Pada Mata Pelajaran Administrasi Server". Jurnal Elinvo (Electronics, Informatics, and Vocational Education), Volume 2, Nomor 2 (hlm. 205-210).

Keniten, I Gede Ngurah Ari. 2017. "Pengembangan Media Pembelajaran Bahasa Jepang Berbasis Adobe Flash Professional CS6 Untuk Meningkatkan Kemampuan Mengingat Kosakata Siswa Kelas XI di SMKN 4 Negara”. Jurnal Pendidikan Bahasa Jepang, Volume 3, Nomor 1 (hlm. 33-43).

Mardani, D.M.S., Sadyana, I.W., \& Adnyani, L.D.S. 2020. Learning Japanese Language Based on 2013 Curriculum at Elementary Schools in Bali. Proceedings of the 3rd International Conference on Innovative Research Across Disciplines (ICIRAD 2019), 246-251. https://dx.doi.org/10.2991/assehr.k.200115.040

Mulyatiningsih, E. 2016. "Pengembangan Model Pembelajaran". Tersedia pada: http://staff.uny.ac.id/sites/default/files/pengabdian/draendangmulyatiningsihmpd/7cpe ngembangan-model-pembelajaran.pdf (diunduh tanggal 25 juni 2019)

Triantari, Ni Komang. 2018. Pengembangan Media Kartu Permainan Remi Shinigami Kaado untuk Penguasaan Kosakata Bahasa Jepang di SMK Pariwisata Triatma Jaya Badung. Skripsi (tidak diterbitkan). Jurusan Pendidikan Bahasa Jepang, Universitas Pendidikan Ganesha. 